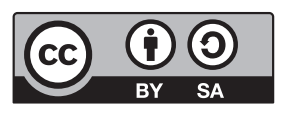

https://doi.org/10.31261/IJREL.2020.6.1.10

\title{
Małgorzata Bartoszewicz
}

Poland

https://orcid.org/0000-0003-0925-8158

\section{Hanna Gulińska}

Poland

https://orcid.org/0000-0002-1272-3818

\section{Mariia Gaidova}

Ukraine/Poland

https://orcid.org/0000-0002-6267-2617

\section{The Use of E-Learning Platform by Flipped Classroom Method in Chemistry Lessons in Poland and Ukraine - Case Study}

\begin{abstract}
The objective of this article is to compare chemistry teaching in Poland and Ukraine at the primary schools level by discussing the possibilities of supporting education using a flipped classroom method (preemptive teaching) and ICT including free Google platform in chemical education. The article peruses some results of tests and surveys carried out among students in Polish and Ukrainian schools in the school year of 2018/2019 pointing out students' motivation regarding ICT teaching support.

K e y w or d s: teaching chemistry, flipped classroom, Poland and Ukraine, ICT, Google platform

The chemistry core curriculum in primary schools in Poland largely resembles the chemistry core curriculum in primary schools in Ukraine. The first years of
\end{abstract}


teaching chemistry in a primary school (in Poland, for 2 years, 2 classes a week, in Ukraine, 3 years, 1.5 classes in the seventh grade, which means 1 class a week and 2 classes every other week, and 2 classes in the eighth and ninth grade) cover the same content. Additionally, there are two levels of education - the basic and the advanced one. The advanced level in Poland starts in high school and takes 3 school years (2.5 years). From 2019/2020, it will take 4 years of learning. In Ukrainian schools, the scope of material depends on a type of school, chemical education starts in the eighth grade and it takes 4 years (specialised schools) or in the tenth grade during the last two years of high school education (specialised classes).

Students in both countries use course books. In Poland, most publishing houses offer additionally electronic workbooks, multi-books, educational video sets facilitating chemical education. Course books in Poland focus more on graphics than on a written content through interesting and modern depiction of learning material in the form of infographics and photos as well as charts presenting chemistry experiments. In Ukrainian course books, learning material is provided in chunks and a written content dominates over graphics with very little attention paid to scientific experiments.

The strategy of preemptive teaching, a flipped classroom, also known as reverse teaching (King, 1993), is a modern teaching method which blends the traditional model of classroom instruction with digital solutions. The main objective of a flipped classroom is the shift of roles in a "student-teacher" dynamic. The roles get reversed and students are encouraged to do their homework prior to a lesson. As for teachers, the method provides them with more tools and time during a class. The strategy of preemptive teaching consists of four stages: activation, processing, systematisation, evaluation and assessment (Dylak, 2013) with relevant activities assigned to each stage.

\section{The Research Problem}

The research's objective was to examine motivation and efficiency of a flipped classroom instructional strategy facilitated by ICT in teaching chemistry in primary schools in Poland and Ukraine. In order for the objective to be achieved, multimedia materials and tests were prepared and placed on the platform. The platform of choice was free educational platform Google Classroom where teachers and students were able to communicate, exchange extra materials and test their newly acquired skills. 
The Use of E-Learning Platform by Flipped Classroom Method in Chemistry Lessons...

The teachers must set up the classrooms and invite students to join them giving them a "classroom code" generated by Classroom or sending them an invitation via an application.

The students from the research and control groups, after joining the virtual classroom, get an access to a tool resembling a social network where in a "classes stream" they can, for instance, share necessary files with their classmates, contact other students and exchange information.

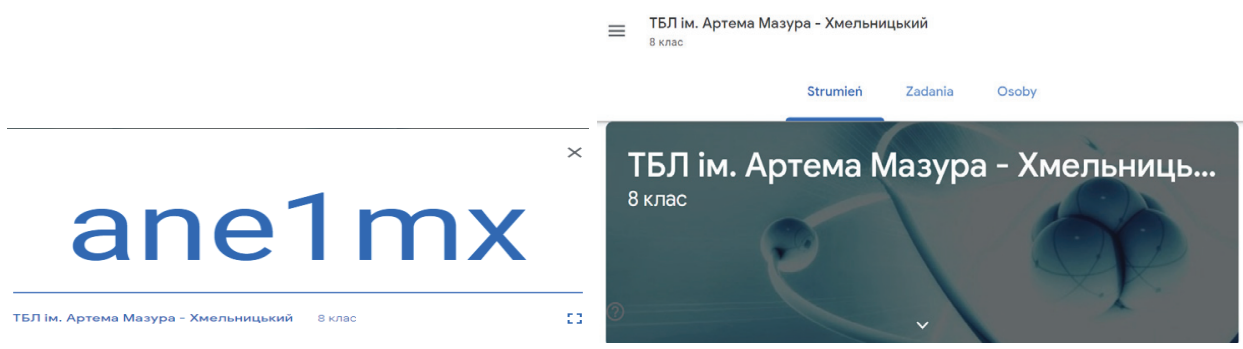

Figure 1. Left - classroom code, right - a website of a selected group S o u r c e: Own work in Google Classroom.

On a website assigned to a particular class, a teacher posts learning materials for students that they have to get familiar with before the lesson - a research group, or after the lesson - a control group. Each topic is added in a separate post with relevant attachments (e.g. presentation, video, follow-up exercises, graphics, test).

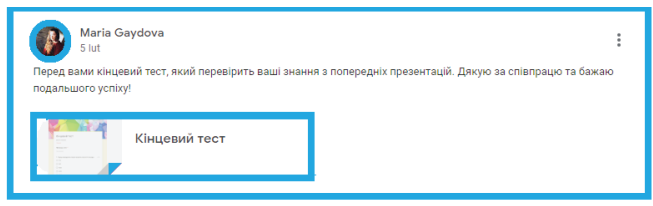

ТБЛ ім. Артема Мазу...

8 клас-gr.b

29 uczniów

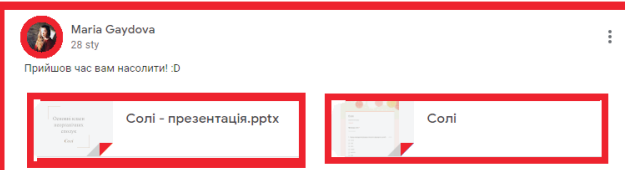

ТБЛ ім. Артема Мазу... :

8 клас - gr.k

14 uczniów

Zespół Szkół Zakonu...

8 klasa - gr.b

15 uczniów

Figure 2. Left - examples of materials, right - schools presented on free Google platform

S o u r c e: Own work in Google Classroom. 


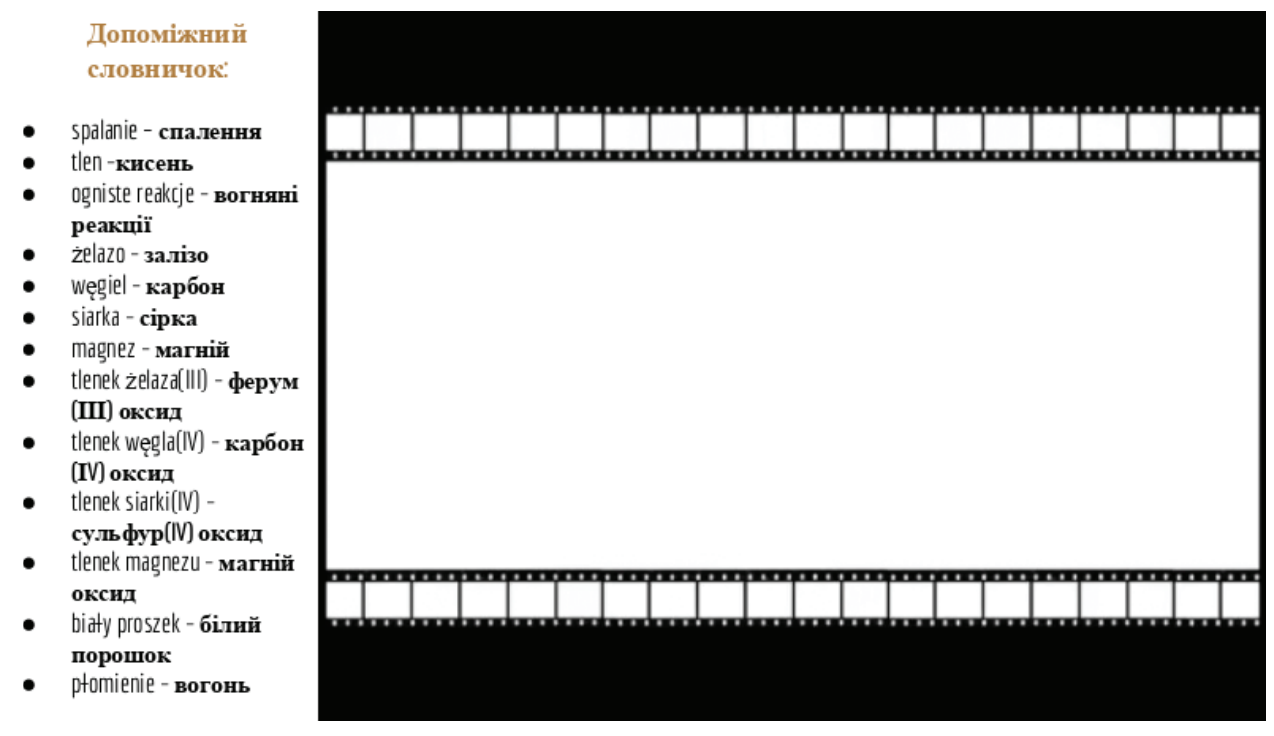

Figure 3. Screen shot from a presentation - video

S o u r c e: Own work in Google Classroom (available online).

N o t e: Students in a Ukrainian school learn Polish - the glossary has been drafted to help students with chemistry terms they were not familiar with up to this point.

\section{Process of Educational Research}

The research covered the students of the seventh and the eighth grade from General Education School Complex no. 4 in Poznań, the St. Józef Kalasancjusz School Complex of Piarists Order in Poznań, and the eighth and the ninth grade of A. Mazur Multi-Profile Technical High School in Khmelnytskyi.

Table 1

No. of students taking part in the research

\begin{tabular}{lccc}
\hline Schools' locations & No. of students & Research group & Control group \\
Poland* & 58 & 31 & 27 \\
Ukraine & 98 & 59 & 39 \\
\hline
\end{tabular}

* Due to teachers' strike in Poland, some topics have not been covered S o u r c e: Own work. 
The Use of E-Learning Platform by Flipped Classroom Method in Chemistry Lessons...

In order to conduct the educational research in all three schools, two classes were selected and divided into the research and the control group. The research group's task was to prepare selected topics at home before the lesson using materials on Google Classroom platform and other sources (e.g. videos from popular science channels and EU projects posted on YouTube, links to websites). The students from control group worked on the same topics in a traditional manner, that is, using the very same materials, doing the same experiments and assignments as homework, only after the lesson. The source of additional learning materials was a computer software Mobilna chemia (Mobile Chemistry), general education e-book Chemia. Świat pod lupa (Chemistry, the World under a Magnifying Glass), other Internet websites and chemistry course books, including Chemia Nowej Ery (Chemistry. The New Era), Ciekawa chemia (Interesting Chemistry), and Xiмiя (Chemistry) for High Schools, to name but a few.

Division of the groups into the research and the control ones involved the whole class and not only the particular groups of students. The research group followed their curriculum using the preemptive method, the control group followed their curriculum in line with the traditional method. The decision concerning the division was based on organisation of school life, ability to communicate the contents and comparable academic achievements in parallel classes.

The task of the research group in the activation and the processing stage (about 45 minutes) was to get familiar with the learning material on the platform and preparing for the class. The students were also allowed to use other sources (course books, the Internet). The final part of the processing stage was a test which helped the students evaluate their knowledge and show a teacher which issues the students struggle with and which issues they failed to comprehend. The systematisation stage gave the teacher a possibility to conduct the lesson in a different, more attractive way. The systematisation stage was established with the teacher during organisation meeting before the research started. The teachers were responsible for conducting the lesson according to a script drafted by Mariia Gaidova as a part of her MA thesis and for motivating their students to study using the preemptive method. This way of cooperation was selected for a reason. First, students are more efficient in learning new contents when it is presented by "their" teacher, they are more focused and less stressed out than when they have to deal with a person they do not know. Secondly, in case of conducting lessons in one school and not conducting them in the other (due to distance and time conditions), the findings would not be suitable for comparison. 


\section{The Research Findings}

The selected topics of the educational research - the case study, from "Non-organic Chemistry" and "Organic Chemistry" were consistent with the core curriculum and distribution of materials in selected schools. "Non-organic Chemistry" unit consisted of four topics: oxides, hydroxides, acids, and salts. "Organic Chemistry" unit consisted of three topics: unsaturated hydrocarbons; alkanes, aaturated hydrocarbons; olefines, saturated hydrocarbons; alkynes.

Students in the research groups got familiar with the materials on the e-learning platform and did partial tests before the lesson, whereas the control group students did their tests after the lesson. Both groups wrote their final tests after completing the entire unit. When the students passed the partial tests, they received the additional points that influenced their final score, which was an additional motivation for them.

Table 2

Collective table - final tests results in percentage

\begin{tabular}{|c|c|c|c|c|c|c|}
\hline Final test & $\begin{array}{l}\text { U 8th } \\
\text { grade } \\
\text { research } \\
\text { group }\end{array}$ & $\begin{array}{l}\text { U 8th } \\
\text { grade } \\
\text { control } \\
\text { group }\end{array}$ & $\begin{array}{l}\text { U 9th } \\
\text { grade } \\
\text { research } \\
\text { group }\end{array}$ & $\begin{array}{l}\text { U 9th } \\
\text { grade } \\
\text { control } \\
\text { group }\end{array}$ & $\begin{array}{l}\text { PL 8th } \\
\text { grade } \\
\text { research } \\
\text { group }\end{array}$ & $\begin{array}{l}\text { PL 8th } \\
\text { grade } \\
\text { control } \\
\text { group }\end{array}$ \\
\hline $\begin{array}{l}\text { Average } \\
\text { results in } \\
\text { points }\end{array}$ & 4.5 & 2.9 & 4.3 & 3.7 & 4.3 & 3.7 \\
\hline $\begin{array}{l}\text { Average } \\
\text { results in } \\
\text { percentage }\end{array}$ & 90 & 58 & 86 & 74 & 86 & 74 \\
\hline
\end{tabular}

U - Ukrainian school, PL - Polish school

S ou rce: Own work

\section{Summary of Results}

As may be seen in a collective Table 2, the final tests results of the Ukrainian and the Polish school, shows that the research groups which applied the preemptive method scored better than the corresponding control groups. The research group from the 8th grade of the Ukrainian school achieved the highest score of $90 \%$, 
The Use of E-Learning Platform by Flipped Classroom Method in Chemistry Lessons...

however it cannot be compared with the corresponding 7 th grade from the Polish school as the final test did not take place because of teachers' strike. The 9th grade of the Ukrainian school achieved the same research result of $86 \%$, as the corresponding 8th grade of Polish school.

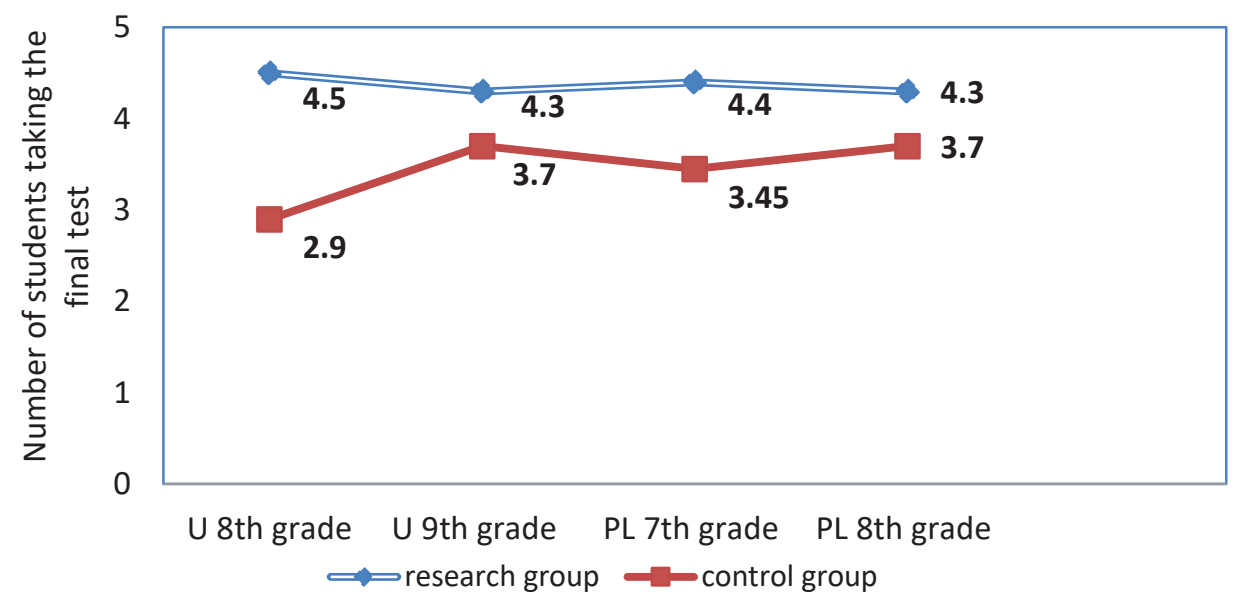

Figure 4. Final test results

S o u r c e: Own work.

N o t e: U - Ukrainian school; PL - Polish school; PL 7th grade total partial test result without final test.

After comparing the average results of the final tests of all groups taking part in the research (expressed by a number of students who took the test), it was concluded that the students of the 8th grade from the Ukrainian school achieved the highest score in the final test, namely $90 \%$. In this class, $84 \%$ of students took the test (24 out of 29 ).

The second highest score, $86 \%$, was achieved by two groups: the research group of the 9th grade from Ukraine (the test was taken by all students) and the corresponding research group of the 8th grade from Poland (the test was taken by 10 out of 15 students).

The result of $74 \%$ in the final test was achieved by: the control group of the 9th grade from Ukraine (the test was taken by all students) and the corresponding control group of the 8th grade from Poland (the test was taken by 8 out of 15 students).

The lowest score was achieved by the control group from the 8th grade in Ukraine which studied using the traditional method. The final result may have been affected by the significant amount of material for the test and the fact that all students took the final tests, not only the best ones. The results of the corresponding 
class, that is, the 7th grade in Polish school could not be taken into account as due to teachers' strike the students did not get the chance to take the final test.

\section{Conclusions}

In order to meet the needs of the modern information society, one must constantly improve the education system. The effectiveness of teaching today's students fully depends on the implementation and use in the study of modern information and communication technologies, including network services that allow you to create an appropriate pedagogy and technology support base of modern information systems for educational purposes (Morze, Spivak, \& Smyrnova-Trybulska, 2014). Therefore, the conducted research has proven to be justified. The collected data demonstrate that all groups involved achieved the average or high scores, however, students from the Ukrainian school were more motivated to learn and interested in ICT materials they were provided with for self-study than their counterparts from the Polish schools. The number of students visiting Google Classroom and attendance in all classes in the Ukrainian school was $94 \%$, whereas the results for the Polish students were respectively $33 \%$ for the 7 th grade and $64 \%$ for the 8 th grade. Not all students used the opportunity to improve their marks with additional points that fostered the right motivation and their desire for self-access learning.

Why did the Ukrainian students spend more time on the learning platform and achieved better results than the students from Poland? The survey and the interviews with the students and teachers revealed that a significant factor was the difference between teaching chemistry in both countries. Schools in Ukraine provide their students with the right equipment and chemical reagents, whereas multimedia resources are less accessible, which makes Ukrainian students more open to gaining new knowledge that is presented in a different, more attractive way. Therefore, the perspective of expending the use of ICT in Ukrainian schools appears to be very encouraging (Nakaznyi, Sorokina, \& Romaniukha, 2015, pp. 60-61). Polish students have an access to more interesting course books, e-workbooks, an opportunity to conduct chemical experiments at school, which could have resulted in a lower motivation to do some extra work outside of the classroom. The lower score and insufficient motivation of the Polish students was also affected by teachers' strike in Poland.

In teaching natural sciences including chemistry, IT may turn out to be very beneficial. Multimedia training has an impact on nearly all human senses and when 
The Use of E-Learning Platform by Flipped Classroom Method in Chemistry Lessons...

compared with traditional teaching it proves to be more efficient when it comes to picking up new knowledge (by 56\%), provides better comprehension of a topic (by $50-60 \%$ ), saves time (by 37-70\%), improves the pace of learning (by 60\%) and the scope of gained knowledge (by 25-50\%), and generates less misunderstanding in transferring knowledge (by 20-40\%) (Steinbrink, 1999), which, in combination with the preemptive teaching, seems promising. In chemical higher education, the student learns laboratory classes at home beforehand, which is the first step to implement the pre-emptive method. There has been an increasing number of reports for flipped learning in chemistry at higher education institutions (Seery, 2015; Melissa, 2017; Pienta, 2016). "The flipped learning approach is likely to be a significant teaching and learning method over the next decade as more educators seek to improve the value and quality of their in-class time by creating a space for active learning. Progress on this will enhance the likelihood that the approach, which is already in favour with students, will be viewed as a rigorous one that can finally challenge the hegemony of the didactic lecture in higher education chemistry" (Seery, 2015, pp. 758-759).

\section{References}

Dylak, S. (2013). Strategia ksztatcenia wyprzedzającego. Poznań: Ogólnopolska Fundacja Edukacji Komputerowej.

Gaidova, M. (2019). Strategy for pre-emptive method education in the Polish and Ukrainian primary school-case study. (Master thesis). Uniwersytet im. Adama Mickiewicza w Poznaniu.

King, A. (1993). From Sage on the Stage to Guide on the Side. Retrieved from: https://www. tandfonline.com/doi/abs/10.1080/87567555.1993.9926781?journalCode $=$ vcol20

Melissa A. (2017). Using Technology To Flip and Structure General Chemistry Courses at a Large Public University: Our Approach, Experience, and Outcomes, (pp 75-97_. In book: Teaching and the Internet: The Application of Web Apps, Networking, and Online Tech for Chemistry Education. ACS Symposium SeriesVol. 1270.

Morze, N., Spivak, S., Smyrnova-Trybulska, E. (2014). Personalised educational environment as one of the trends of modern education (pp. 158-166). In Information and communication technology in education. Proceedings. Roznov pod Radhostem, Czech Republic, 9-11 September, 2014. Ostrava: University of Ostrava, Pedagogical Faculty, 2014.

Nakaznyi, M., Sorokina, L., Romaniukha M. (2015). ICT in Higher Education Teaching: Advantages. Problems, and Motives. International Journal of Research in E-learning, 1(1), pp. 49-61.

Pienta, N. J. (2016). A "Flipped Classroom" reality check. Journal of Chemical Education, 91(1), 1-2.

Seery, M. (2015). Flipped learning in higher education chemistry: emerging trends and potential directions. Chem. Educ. Res. Pract., 2015, 16, pp. 758-768.

Steinbrink, B., (1999). Multimedia. U progu technologii XXI wieku. Wrocław: Wydawnictwo Robomatic.

IJREL.2020.6.1.10 p. 9/12 


\title{
Course books
}

Bartoszewicz M., Gulińska H. (2016). Mobilna chemia (Mobile Chemistry). Wrocław: Multiedukacja, Gulińska H., Smolińska J. (2018). Ciekawa chemia (Interesting Chemistry). Warszawa: WSiP.

Kulawik J., Kulawik T., Litwin M. (2018). Chemia Nowej Ery (New Era Chemistry). Warszawa: New Era.

Popel' P.P., Kriklâ L.S., (2016). Himiâ. Kiev: Izdatel'skij centr «Akademîa» (Popel P.P., Kriklya L.S., (2016). Хімія (Chemistry). Kiev: Academiya Publishing Center) (Попель П.П., Крикля Л.С., (2016). Химия. Киев: Издательский центр «Академия») (In Russian).

Małgorzata Bartoszewicz, Hanna Gulińska, Mariia Gaidova

\section{Wykorzystanie platformy e-learningowej metodą odwróconej klasy na lekcjach chemii w Polsce i na Ukrainie - studium przypadku}

\author{
Streszczenie
}

Celem artykułu jest porównanie nauczania chemii w Polsce i na Ukrainie na poziomie szkoły podstawowej poprzez omówienie możliwości wspomagania kształcenia z wykorzystywaniem metody odwróconej klasy (nauczania wyprzedzającego) oraz ICT w tym darmowej platformy Google w edukacji chemicznej. Niniejszy artykuł analizuje niektóre wyniki testów i ankiet przeprowadzone wśród uczniów szkoły polskiej i ukraińskiej w roku szkolnym 2018/2019 wskazując motywacje uczniów dotyczące wspomagania nauczania ICT.

Słowa kluczowe: nauczanie chemii, odwrócona klasa, Polska i Ukraina, ICT, platforma Google

Małgorzata Bartoszewicz, Hanna Gulińska, Mariia Gaidova

Использование платформы электронного обучения методом перевернутого класса на уроках химии в Польше и Украине тематическое исследование

А н но т а ия

Цель этой статьи - сравнить преподавание химии в Польше и Украине на уровне основной школы, обсудив возможности поддержки образования с использованием метода перевернутого класса (упреждающее обучение) и ИКТ, включая бесплатную платформу Google на примере химического образования. В статье рассматриваются некоторые результаты тестов и опросов, проведенных среди учащихся польских и украинских школ в 2018/2019 учебном году, которые указывают на мотивацию учащихся в отношении поддержки обучения ИКТ.

IJREL.2020.6.1.10 p. 10/12 
The Use of E-Learning Platform by Flipped Classroom Method in Chemistry Lessons...

К л ю ч е в ы е с л о в а: преподавание химии, перевернутый класс, Польша и Украина, ИКТ, платформа Google

Małgorzata Bartoszewicz, Hanna Gulińska, Mariia Gaidova

\title{
El uso de la plataforma de e-learning en las clases de química. por método de aula invertida en Polonia y Ucrania - estudio de caso
}

\author{
Resumen
}

El objetivo del artículo es comparar la enseñanza de la química en Polonia y Ucrania a nivel de escuela primaria discutiendo las posibilidades de apoyar la educación con el uso del método de clase invertida (educación preescolar) y las TIC, incluida la plataforma gratuita de Google en educación química. El artículo analiza algunos de los resultados de las pruebas y encuestas realizadas entre estudiantes de escuelas polacas y ucranianas en el año académico 2018/2019, indicando la motivación de los estudiantes para apoyar la enseñanza de las TIC.

P a labras clave: enseñanza de química, aula invertida, Polonia y Ucrania, TIC, plataforma Google 